\title{
ADVANCING SPORTS AND HEALTH-IMPROVING WORK IN PLACES OF PRE-TRIAL DETENTION AND PENITENTIARY INSTITUTIONS BY DEVELOPING THE EDUCATIONAL COMPONENT
}

\author{
Tetyana Prots ${ }^{1}$, \\ ${ }^{I}$ Postgraduate student of the Management Department, Lviv Regional Institute for Public Administration of \\ the National Academy for Public Administration under the President of Ukraine, Lviv, Ukraine, e-mail: \\ tap_lridu@i.ua,ORCID ID:0000-0002-6771-1881.
}

\begin{abstract}
The normative-legal, organizational, material-technical, personnel and educational-methodical support of physical culture and health-improving work in places of pretrial detention and penitentiary institutions is analyzed. The aim of the article: to develop an educational component for advancing sports and health-improving work in places of pre-trial detention and penitentiary institutions. There is substantiated the necessity for better coordination of interactions between the subjects of the spheres - public authorities, State Penitentiary Service of Ukraine, education, physical culture and sports, civil society institutions (public associations of physical culture and sports) to ensure the quality of training and performance of specialists/employees; improving the organizational, regulatory, personnel, logistical, financial, information support for a fuller realization of the social role of physical culture, in particular in this area; there is deepened the meaning of the concept of "educational component of physical culture and sports as health-improving activities in the places of pre-trial detention and penitentiary institutions" by determining the impact of European integration processes aimed at radical reforming of the penitentiary system, the content and forms, mechanisms and tools for improving efficiency and effectiveness of professional training of employees of the penitentiary system in terms of their physical fitness. We have found out that in the educational programs of the Academy of State Penitentiary Service of Ukraine such disciplines as "Physical Education" and "Special Physical Training" are aimed at forming theoretical knowledge, practical and methodological abilities in physical education as components of their full, harmonious and safe life; gaining experience in the application of acquired values throughout life in private, educational, professional activities; ensuring the appropriate level of development of physical performance; promoting the development of professional, ideological and civic qualities.

Key words: places of pre-trial detention, public authorities, educational component of physical culture and health work, penitentiary system, public management of development of education in the field of physical culture, special physical training, physical education.
\end{abstract}

JEL Classification: H83, K14, Z28

Formulas: 0; fig.: 1; tabl.: 0; bibl.: 20.

Introduction. Implementation of the state strategic task - assigning physical culture and sports in Ukraine a leading role as an important factor in a healthy lifestyle, disease prevention, the formation of humanistic values, creating conditions for comprehensive harmonious human development, promoting physical and spiritual perfection, identifying reserve capacity, forming patriotic feelings of citizens and a positive image of the state in the world community [1] largely depends on state support for the development of education in the field of physical culture and grassroots sports in Ukraine, in particular at the regional level. The educational component is one of the determining factors in the development of physical culture in 
its main areas, in particular in sports and health activities in places of pre-trial detention and at penitentiary institutions, and "taking into consideration European integration processes aimed at radical reforming of the penitentiary system, the requirements for improving the reliability and efficiency of professional training of employees of the penitentiary system have changed. One of the components of their readiness to perform their professional duties is physical fitness, which is provided by the process of physical education in a higher education institution" [2].

Literature review. Various aspects of public administration in the field of physical culture and sports in Ukraine are covered in the works of B. Averyanov, O. Andriiko, V. Bazenko, E. Borodin, V. Husar, M. Dutchak, V. Zhukov, I. Zaliubovska, N. Kalashnyk, V. Kudelko, O. Kuzmenko, C. Lishchuk, Y. Michuda, M. Oliinyk, M. Studenikina, in particular, the issues of managing the development of education in the field of physical culture were studied by such scientists as V. Andrushchenko, T. Boichenko, C. Vavreniuk, I. Hasiuk, V. Horashchuk, O. Dubohai, M. Dutchak, O. Mozolev, L. Sushchenko, O. Shiian. The issues of combining general and special physical training, use in the educational process of specialized physical training of elements of high sports technologies and methods, methodology and sports pedagogy of training specialists for the penitentiary system were studied by V. Boiko, M. Bulatova, L. Volkov, A. Holovach, V. Dakhnovskyi, T. Ishchenko, A. Laputin, S. Leshchenko, F. Mohilnyi, M. Nosko, V. Platonov, Y. Pokholenchuk, N. Razumeiko, O. Sukhomlynska, B. Shiian and others. However, there is a lack of research on the issue of improving sports and health in the places of pre-trial detention and penitentiary institutions through enhancing the educational component.

Aims. The aims of the article is to develop an educational component for advancing sports and health-improving work in places of pre-trial detention and penitentiary institutions.

Methods. To solve this goal, the following research methods were used: observation and generalization; ordering of all basic elements; method of scientific generalization, which made it possible to formulate conclusions.

Results. Given the different types of activity and its subjects (Fig. 1), the concept of education in the field of physical culture in terms of volume and content has several meanings: educational component of activity of subjects of physical culture or educational training in physical culture and sports; specialized sports education; pedagogical education in the field of knowledge «01 Education» in the speciality «Physical Culture and Sports» [3].

The educational component of sports and health-improving activities in the places of pre-trial detention and penitentiary institutions is a process of acquiring and developing competencies of subjects - "a dynamic combination of knowledge, skills and practical skills, ways of thinking, professional, ideological and civic qualities, moral and ethical values that determine a person's ability (citizen) to carry out professional and further educational activities successfully and is the result of training)" [4]. 
The content and forms, mechanisms and tools for the implementation of the educational component in ensuring the development of sports and health activities in the places of pre-trial detention and penitentiary institutions have their own characteristics, due to the specifics of this area. First of all, it is the presence of two different or even somewhat "opposite" groups of subjects: prisoners and employees of penitentiary institutions, for which such basic concepts as "physical culture" (the activity of subjects of the sphere of physical culture and sports, aimed at ensuring motor activity of people for the purpose of their harmonious, especially physical, development and leading a healthy lifestyle), "physical education" (the direction of physical culture associated with the process of educating a person, acquiring appropriate knowledge and skills to use physical activity for comprehensive development, rehabilitation and readiness for professional activity and active participation in public life), "physical training" (a component of physical education of various groups, which is about forming motor skills and abilities of a person, developing his/her physical qualities and abilities, taking into account the characteristics of professional activity) [5] acquire substantive differences and are implemented in different forms and outlined spaciotemporal measurements. For these groups of subjects, the legal definition and regulation of physical education are different: for citizens who are in the places of pre-trial detention and penitentiary institutions - it is "sports and health activities"; for employees of these institutions it is "physical training - a discipline that is a part of the overall system of education and upbringing and is aimed at ensuring the physical fitness of ordinary and senior staff for the professional activity" [6].

\begin{tabular}{|c|c|c|c|}
\hline \multicolumn{4}{|c|}{ Field of physical culture } \\
\hline \multicolumn{4}{|c|}{ Callisthenics } \\
\hline \multirow{5}{*}{$\begin{array}{l}\text { Physical } \\
\text { Education }\end{array}$} & \multirow{4}{*}{$\begin{array}{c}\text { subjects of } \\
\text { activity }\end{array}$} & individuals & $\begin{array}{l}\text { gymnasts, athletes, specialists in the } \\
\text { field of physical culture and sports }\end{array}$ \\
\hline & & \multirow[t]{2}{*}{ entities } & $\begin{array}{l}\text { establishments of physical culture and } \\
\text { sports }\end{array}$ \\
\hline & & & relevant public authorities \\
\hline & & civil society institutions & $\begin{array}{l}\text { public associations of physical and } \\
\text { sports orientation }\end{array}$ \\
\hline & \multicolumn{3}{|c|}{$\begin{array}{l}\text { educational preparation } \\
\text { (education in the field of physical culture) }\end{array}$} \\
\hline
\end{tabular}

Fig. 1. Subjects of education in the field of physical culture

Sports and health-improving activity of citizens who are in the places of pre-trial detention and penitentiary institutions is defined by Article 32 of the Law of Ukraine "On Physical Culture and Sports", namely [7]: citizens who are in the places of pre- 
trial detention and penitentiary institutions are guaranteed the opportunity to do sports and health-improving activities; the administration of the sites of pre-trial detention and penitentiary institutions creates conditions for physical education for persons who are in there, in particular for minors, conditions for physical education following the requirements for physical education, provided for secondary and vocational schools; The central authority of executive power, which ensures the formation of state policy in the field of execution of criminal punishments, determines the procedure for carrying out sports and health-improving activity and regulations for providing places of pre-trial detention and penitentiary institutions with physical culture and sports implements and equipment.

The State Penitentiary Service of Ukraine has 182 penitentiary institutions in which, as of January 1, 2020, 52,863 persons were detained [8]. Rules of procedure of pre-trial detention centers [9] and penitentiary institutions [10] determine the procedure for sports and health-improving activities of persons in the places of pretrial detention and penitentiary institutions. Thus, the Rules of procedure of the pretrial detention centers of the State Penitentiary Service of Ukraine provide for "walking yards for prisoners and convicts to walk on the territory of the regime zone or the roof of the regime building. In the courtyards are installed sports equipment for exercise (crossbar, bars). For minors in the courtyards, it is recommended to equip playgrounds for mini-football, basketball, volleyball, table tennis and more. In each walking yard, the bench which is reliably fastened to a floor is established. Sandboxes and swings are arranged for children under three years old. To organize leisure, prisoners and convicts are given board games (chess, checkers, dominoes, backgammon, other logic games) for the cells (living quarters) at the rate of one set for four people" [11]. Rules of procedure of penitentiary institutions [12] provide for the realization of the right of convicts: to be engaged in physical culture and do sports, to use a library, board games; wear sportswear and footwear during sports events and in free time following the daily routine; to receive education in accordance with the legislation on education. Sports and health-improving events among convicts are carried out at the time established by the agenda and within rules of procedure of the penitentiary institution. In correctional colonies of a minimum level of security with facilitated conditions of detention, correctional centers and sections of social rehabilitation (adaptation), such measures may be carried out outside the residential area of the penitentiary institution, but within the location of the institution. The administration of the penitentiary institution takes steps to provide convicts with sports equipment, inventory and board games (chess, checkers, backgammon, dominoes), which convicts can use in their free time. For convicts held in a disciplinary isolator, a cell-type room (solitary confinement), a dungeon and a celltype cell of correctional colonies (sectors) of the maximum level of security, a crossbar and a bar are installed in the playgrounds.

Thus, the legislation sets minimum conditions for doing sports by citizens who are in the places of pre-trial detention and penitentiary institutions. Physical culture 
and health-improving activity in the places of pre-trial detention and penitentiary institutions is reduced to: guaranteeing an opportunity to be engaged in physical culture and health-improving activity; creation of conditions for physical culture classes for persons who are in them, in particular for persons who have not reached the age of majority, - conditions for physical education following the requirements for physical culture classes provided for secondary and vocational schools; ensuring the formation of state policy in the field of execution of punishments; provision of places of pre-trial detention and penitentiary institutions with physical culture and sports equipment [13].

Another state of affairs with sports and health-improving activities of the staff of authorities, institutions and establishments of the State Penitentiary Service of Ukraine, in which: numerous sports competitions are held, and the administration considers the development of physical culture and sports and creation of the corresponding sports base as one of priority directions of work with the personnel [14]; general and special physical training is regulatory defined as a mandatory part of the comprehensive system of vocational training and is aimed at ensuring the physical readiness of rank and file and command staff for professional activities [15].

The Regulation on the organization of vocational training of rank and file and command staff of the State Penitentiary Service of Ukraine specifies that it is conducted during training sessions according to the training program under the schedule of training sessions at the place of service throughout the calendar year at the rate of 3 academic hours per week, which are planned and held separately for males and females; individual physical training classes; holding mass sports events. Physical training of privates and officers is carried out on the basis of orders of the Administration of the State Penitentiary Service of Ukraine, interregional departments, bodies and institutions of the State Penitentiary Service of Ukraine, and includes: organization of sports sections; carrying out of sports and health-improving events; organization and holding of training meetings; organization and holding of sports competitions. It is envisaged that at the beginning of each quarter of the school year at scheduled classes the check on the physical fitness of rank and file and command staff by selected 1-2 exercises by the head of the body or institution of the State Penitentiary Service Ukraine, according to the list of standards for general physical training for rank and file and command staff of the State Penitentiary Service and cadets of the State Penitentiary Service educational institutions. Persons of the rank and file and command staff who have met the standards during the inspections of their physical fitness may engage in physical training through individual pieces of training. These pieces of training are held at the expense of hours provided for physical exercise in the training system, and in the off-hours at the sports base at the place of service or other sports facilities of any form of ownership. If those of the rank and file and command staff received an "unsatisfactory" grade during the inspection, they are involved in physical training classes in the current school quarter on general terms according to the schedule of training sessions [16]. 
The content of this Regulation on the main aspects of the organization of physical education and areas of improving special physical training extends to the training of cadets of the only departmental institution of higher education of the State Penitentiary Service of Ukraine - the Academy of State Penitentiary Service of Ukraine (Chernihiv), which at one time in the past was suggested by the Ministry of Justice of Ukraine to be reorganized together with the Institute of Law and Postgraduate Education, which is Bila Tserkva, Dnipro and Khmelnytsky Centers for Vocational Education of the Personnel of the State Penitentiary Service of Ukraine into the Academy of Justice of Ukraine as a higher education institution with specific training conditions [17]. Currently, the Academy of the State Penitentiary Service of Ukraine provides state-funded training for about one thousand people in full-time and extramural forms of education of "Bachelor" and "Master" degrees in the speciality of "Law Enforcement" and field of knowledge "Law" provide 6 cycles, which unite 226 employees, including 11 doctors of sciences and 38 candidates, associate professors [18].

The main activity of the Academy is professional training to meet the needs of the State Penitentiary Service of Ukraine by the state order and contractual obligations of qualified specialists with higher education in the field of knowledge "Law", "Social and Behavioral Sciences", as well as for government authorities, entrepreneurship, higher education, science, other fields in Ukraine and other countries; carrying out activities related to professional training (initial professional training, retraining and advanced training) of the personnel of the State Penitentiary Service of Ukraine in the structural units of the Academy; advanced training of the staff of State Penitentiary Service of Ukraine; providing an organic combination in the educational process of educational, scientific and innovative activities, popularization of science; conducting scientific activity by doing research and ensuring the creative activity of participants in the educational process, training of highly qualified scientific personnel and the use of the obtained results in the educational process [19].

In the educational programs of the Academy of the State Penitentiary Service of Ukraine "Physical Education" and "Special Physical Training" are normative and interrelated disciplines that are essential components of the process of education and upbringing. Physical training of cadets is aimed at "forming knowledge, skills and abilities on the managing physical development of a person through physical education, applying the acquired abilities in the vital activity of future experts", and it has the following tasks: "forming bases of theoretical knowledge, practical and methodical abilities by cadets in physical education as components of their full, harmonious and safe life; gaining experience in the application of acquired values throughout life in personal, educational, professional activities, in everyday life and within the family; ensuring the proper level of development of indicators of their functional and morphological capabilities of the organism, physical qualities, motor 
abilities, efficiency; promoting the development of professional, ideological and civic qualities of cadets; training and participation of cadets in various sports events" [20]

Instead, the purpose of specialized physical training is aimed at ensuring the physical ability of staff to work and act in extreme situations. Specialized physical training consists of mastering the skills of hand-to-hand combat, SAMBO as necessary professional competencies and individual physical, personal moralpsychological and ideological-volitional qualities of a penitentiary service employee.

Discussion. The results obtained during the study of ways and means of advancing sports and health-improving work in places of pre-trial detention and penitentiary institutions, in contrast to the before mentioned works of other researchers, relate to highlighting and specificating of ways and means of improving physical culture and sports in this area by developing the educational component.

Conclusions. As a result of the analysis of normative-legal, organizational, material-technical, personnel and educational-methodical support of sports and health-improving work in places of pre-trial detention and penitentiary institutions it was found out that:

- the educational component in conditions of the implementation of European integration processes, aimed at radical reform of the penitentiary system, is one of the determining factors in the development of sports and health-improving activities in places of pre-trial detention and penitentiary institutions because it contributes to the requirements for improving the reliability and efficiency of professional training of employees of the penitentiary system in terms of their physical preparedness;

- the educational component of sports and health-improving activities in the places of pre-trial detention and penitentiary institutions is a process of acquiring and developing competencies of subjects - a dynamic combination of knowledge, skills and practical skills, ways of thinking, professional, ideological and civic qualities, moral and ethical values that determine a person's ability (citizen) to carry out his/her professional activity successfully; a factor of a healthy lifestyle, disease prevention, formation of humanistic values, creation of conditions for comprehensive harmonious human development, promotion of physical and spiritual perfection, identification of reserve capabilities of the organism, formation of patriotic feelings in citizens and positive image of the state in the world community;

- content and forms, mechanisms and tools for the implementation of the educational component in ensuring the development of sports and health-improving activities in the places of pre-trial detention and penitentiary institutions have their own characteristics due to the specifics of this area, including the presence of two different groups - prisoners and employees of penitentiaries;

- sports and health-improving activity in places of pre-trial detention and penitentiary institutions is to implement the legally established minimum conditions for doing sports of the citizens who are in these places of pre-trial detention and penitentiary institutions; 
- physical culture and health-improving activity of the personnel of authorities, institutions and establishments of the State Penitentiary Service of Ukraine, is one of the priority directions of work with the staff; general and special physical training is normatively defined as a mandatory part of the general system of professional training and is aimed at ensuring the physical readiness of rank and file and command staff for professional activities;

- in the educational programs of the Academy of State Penitentiary Service of Ukraine normative and interrelated disciplines "Physical Education" and "Special Physical Training" is directed at forming bases of theoretical knowledge, practical and methodical abilities in physical education as components of full, harmonious and safe life; gaining experience in the application of acquired values throughout life in personal, educational, professional activities, in everyday life and within the family; ensuring the proper level of development of indicators of their functional and morphological capabilities of the organism, physical qualities, motor abilities, efficiency; facilitating the development of professional, ideological and civic qualities;

- the expediency of better coordination of interactions between public authorities, institutions and establishments of the State Penitentiary Service of Ukraine, spheres of education and physical culture and sports and civil society institutions (civic associations/NGOs of physical culture and sports) to ensure the quality of training and performance of specialists.

In the perspective of further studies in the direction of the research of public administration of the development of education in the field of physical culture, it is advisable to carry out a structural and functional analysis of the interaction of specified entities.

\section{References:}

1. The concept of the State target social program for the development of physical culture and sports for the period up to 2020 (2017), [dated 01.03, 115], retrieved from: https://zakon.rada.gov.ua/laws/show/1152017-\%D0\%BF\#n10.

2. Golovach, A., Mohylny, F. (2017), Basic aspects of the organization of special physical training in educational institutions of DKVS of Ukraine. Bulletin of the National University "Chernihiv Collegium" named after TG Shevchenko, 144, 15-19.

3. Prots, T., Vasylyuk, O. (2020), Normative and legal regulation of training and use of specialists in the field of physical education: regional aspect. Zarzadzaie - Bezpieczenswo. Wybrane aspekty, [Wizsza Szkola Bezpieczestwa i Ochrony im. Marszalka Jozefa Pilsudskigo w Warszawie. Widzial Zamiejscowy w Nisku], 5, 13-14.

4. About Physical Culture and Sport: Law of Ukraine (1993), [dated 24.12, 3808-XII], retrieved from : https://zakon.rada.gov.ua/laws/show/3808-12.

5. Regulations on the organization of professional training of members of the rank and file and senior staff of the State Criminal-Executive Service of Ukraine (2015)), [dated 08.09, 1675/5], retrieved from : https://zakon.rada.gov.ua/laws/show/z1088-15.

6. About Physical Culture and Sport: Law of Ukraine (1993), [dated 24.12, 3808-XII], retrieved from : https://zakon.rada.gov.ua/laws/show/3808-12.

7. State Tax Service of Ukraine: General information (2020), retrieved from : https://kvs.gov.ua/2019/harakteristika/01.01.2020.pdf.
8. State
Tax
Service of Ukraine:
General
information
(2020),
retrieved from 
https://kvs.gov.ua/2019/harakteristika/01.01.2020.pdf.

9. Rules of internal procedure of pre-trial detention centers of the State Criminal-Executive Service of Ukraine (2019), [dated 14.06, 1769/5], retrieved from : http://search.ligazakon.ua/__doc2.nsf/link1/RE33604.html.

10. Rules of internal procedure of penitentiary institutions (2018), [dated 28.08., 2823/5], retrieved from : https://zakon.rada.gov.ua/laws/show/z1010-18.

11. Rules of internal procedure of pre-trial detention centers of the State Criminal-Executive Service of Ukraine (2019), [dated 14.06, 1769/5], retrieved from : http://search.ligazakon.ua/1_doc2.nsf/link1/RE33604.html.

12. Rules of internal procedure of penitentiary institutions (2018), [dated 28.08, 2823/5], retrieved from : https://zakon.rada.gov.ua/laws/show/z1010-18.

13. On the State Penitentiary Service of Ukraine: Law of Ukraine (2005), [dated 23.06, 2713-IV], retrieved from : https://zakon.rada.gov.ua/laws/show/2713-15.

14. Kharkiv penitentiaries celebrated the Day of Physical Culture and Sports, retrieved from : https://www.kvs.gov.ua/peniten/control/khe/uk/search/control/khe/uk/publish/article/796455;jsessionid=6E5 38A03896856A980AE9F838D90F3E0.

15. Regulations on the organization of professional training of members of the rank and file and senior staff of the State Criminal-Executive Service of Ukraine (2015), [dated 08.09, 1675/5], . retrieved from : https://zakon.rada.gov.ua/laws/show/z1088-15.

16. Regulations on the organization of professional training of members of the rank and file and senior staff of the State Criminal-Executive Service of Ukraine (2015), [dated 08.09, 1675/5], retrieved from : https://zakon.rada.gov.ua/laws/show/z1088-15.

17. Some issues of the establishment of the Academy of Justice of Ukraine (2019), [a draft resolution of the Cabinet of Ministers of Ukraine], retrieved from : http://spo.fpsu.org.ua/images/2019/2080$\% \mathrm{D} 1 \% 81 \% \mathrm{D} 0 \% \mathrm{~B} 0 \% \mathrm{D} 0 \% \mathrm{~B} 9 \% \mathrm{D} 1 \% 82 . p d f$.

18. Academy of the State Penitentiary Service of Ukraine, retrieved from : https://uk.wikipedia.org/wiki/ Academy_of_the_State_Penitentiary_Service_of_Ukraine.

19. Charter of the Academy of the State Penitentiary Service of Ukraine (2016), [new edition, Chernihiv], retrieved from : http://academysps.edu.ua/wp-content/uploads/2019/12/Statut-Akademii-DPtS.pdf.

20. Golovach, A., Mohylny, F. (2017), Basic aspects of the organization of special physical training in educational institutions of DKVS of Ukraine. Bulletin of the National University "Chernihiv Collegium" named after TG Shevchenko, 144, 15-19. 